\title{
The Use of Sterile Razors as an Efforts to HIV/ AIDS Transmission Prevention
}

\author{
Yuniar Wardani, Liena Sofiana, Suci Musvita Ayu, Erni Gustina, Marsiana \\ Wibowo, Fardhiasih Dwi Astuti, Septian Emma Dwi Jatmika \\ Department of Public Health, Faculty of Public Helath, Universitas Ahmad Dahlan, Yogyakarta
}

\section{Article Info}

Article history:

Received Sep 21, 2017

Revised Nov 24, 2017

Accepted Dec 15, 2017

\section{Keyword:}

Attitude

Behavior

HIV/AIDS

Knowledge

\begin{abstract}
HIV Transmission can also occur as a result of the employment relationship. In addition to health workers there are other workers who are in close contact with his client was a barber, hairdresser, masseur, tattoo, ear piercer and acupuncturist. The purpose of this study was to determine the behavior of a barber in the prevention of transmission of HIV/AIDS with the use of a sterile razor blade. The study design was cross-sectional survey and data analysis is performed simultaneously with quantitative descriptive approach. This study was conducted in the district of Yogyakarta Special Region of Yogyakarta. Subjects of the study were all traditional barber in the study area. The sampling technique used purposive sampling with certain criteria under the terms set by the researchers. The data analysis used Spearman. The average age of respondents was 30.91, the number of consumers 31.28. Mean knowledge is 34.09 , attitudes and behavior amounting to 31.06 . Based on the rate most people are able to reach a price set by a razor because the tariff ranges between IDR 6,000-10,000 and an average tariff of IDR 8,230. On average shaver have 32 customers each month. There was a correlation between knowledge, attitude with behavior of a barber in the prevention of transmission of HIV/AIDS. There was a correlation between knowledge, attitude and behavior to conduct barber in the prevention of transmission of HIV/AIDS.
\end{abstract}

Copyright (c) 2017 Institute of Advanced Engineering and Science. All rights reserved.

\section{Corresponding Author:}

Yuniar Wardani,

Department of Public Health Science, Faculty of Public Health,

Universitas Ahmad Dahlan,

Jl. Prof. Dr. Seopomo, Janturan, Yogyakarta, Indonesia 55164.

Email: yuniar.wardani@ikm.uad.ac.id

\section{INTRODUCTION}

HIV and AIDS surfaced in Indonesia, beginning with the discovery of the first case in 1987 in Bali. By the year 2000, an accelerated accretion. People with HIV and AIDS (PLWHA) by leaps and bounds, even into 2000, there are locations where HIV transmission is high (Concentrated Epidemic Level). The purpose of Sustainable Development Goals (SDGs) is one of them is to combat Human Immunodeficiency Virus (HIV) [1]. The disease associated with acquired immunodeficiency syndrome (AIDS) is one of the leading causes of death worldwide. In Indonesia, currently the number of people living with HIV AIDS reaches 291,465 people in the place of death numbers totaling 14,234 people [2].

The risk factors that are expected to increase the incidence of HIV/AIDS, among others: Socioeconomic environment, especially poverty, cultural background/ethnicity, demographic situation (the number of ports visited by foreigners). Groups of people who potentially have a high risk of HIV are: Status of donor blood (blood transfusion recipients, donor blood if the tools are not sterile), infants of mothers who are diagnosed with AIDS (the process of pregnancy, birth and breastfeeding), drug users (especially IDU, piercing the tool exposed to HIV/AIDS). AIDS transmission can also occur as a result of the employment 
relationship. In this case the work of the victim has a major role in the occurrence of infection. Health workers who deal with people with AIDS have a higher propensity to become infected with HIV as a result of the work. Health workers who are vulnerable to AIDS infection is a blood bank technician, technicians brow health, emergency room personnel, mortuary, dentists, surgeons, and laboratory workers. In addition to health care workers there are other workers who are in close contact with his client was a barber, hairdresser, masseur, tattoo, ear piercer and acupuncturist [3].

Barber shop is having the hair to the barber is a routine job everyone to beautify the appearance. Unlike women who choose to shave to the beauty salon, men prefer to go to the barber roadside. This is because in terms of the cost more affordable. When shaved, one does not realize there are wounds caused by scratches on the shaver. Wounds that are not visible by naked eye are pretty big gate as an entrance or exit of a disease. Some diseases that can arise through this transmission is HIV/AIDS, Hepatitis B and Hepatitis C. Shaving place Hair is one where people use razors and places that do not have sterilizing equipment. Customers who use barber services to cut hair are at risk of being scratched by a razor when the scalp is shaved [4]. Transmission is possible due to lack of cleanliness of shaving equipment. Sometimes, barbers do not clean the razors immediately after use. Barbers also do not use disinfectant or soap when cleaning razors, just clean with a plain fabric) [5].

Result of study in developed countries report that $93 \%$ of barbers have a high awareness about HIV transmission [6]. While in Asia, only 50\% of barbers are aware of the importance of sterile razors to prevent transmission. Some barbers in Indonesia also accept customers who shave mustaches, beards and others, who also have a risk of HIV transmission. The results show that $78 \%$ of HIV can be transmitted by sharing unsteady sharp instruments. There are $48 \%$ of respondents have correct knowledge about the meaning of sterilization and $94.1 \%$ of them believe the importance of sterilization in the workplace [7]. The results showed that $52 \%$ of barbers had less knowledge about HIV / AIDS transmission through a razor, $47 \%$ have negative attitude towards disease transmission. Only 32\% repondens who used disinfectan after shaving [8].

Total barber in the city of Yogyakarta, Indonesia have counted because there was no registration against the barber's. Researchers estimate their numbers around 550 people assuming these researchers error rate is $5 \%$ of the total respondents were 110 people barber. The characteristics of the barber in the city of Yogyakarta, among others: have a permanent stall, put up signs barber, using traditional tools and modern and most use a razor blade to be used interchangeably without sterilization process. In fact the group's barber largely untouched by government policies relating to the prevention of HIV/AIDS, but these groups are especially vulnerable as a transmitter of disease. One of the prevention of transmission of HIV/AIDS is to do sterilization the shaver or by using a disposable razor for one customer. Nevertheless, one cannot force the barber to apply the principle of sterilization as in clinics. The barber is much more expensive costs incurred when applying sterilization, so no guarantee that the customer is free of HIV/AIDS.

The role of the barber as the mediator prevention of HIV/AIDS is very important. However, because the barber has not play a role in prevention of this disease, it needs to be an assessment of the knowledge and attitudes possessed by a barber. In the end, the level of knowledge and attitude barber can be used as study materials in the preparation of health promotion media, then the media campaign which has so going to test for effectiveness and if it is proven effective then media campaign will be registered as intellectual property. Assumptions researchers, when the barber learn about the knowledge, attitudes and behavior will most likely be able to change the behavior that do not pay attention to sterile razor blade into the behavior using sterile razor blades. Good knowledge will make the barber think and try to prevent the spread of HIV/ AIDS transmission through razor transmission. In the process of thinking, emotional components and beliefs work, so the barber intends to use a sterile razor for each customer to avoid the spread of the HIV virus through razor transmission [9].

Based on the exposure, the researchers wanted to examine the role of the barber as mediators of the HIV/AIDS prevention through the assessment of knowledge and attitude held by the barber with behavioral prevention against HIV/AIDS.

\section{RESEARCH METHOD}

This study was survey research with cross-sectional design. This research was conducted in the district of Yogyakarta Special Region of Yogyakarta, Indonesia. The reasons for selecting the location in the city of Yogyakarta is based on the high incidence and prevalence of HIV compared to four other districts. The subject of his research is all traditional barbers in the research area. The sampling technique used purposive sampling that meet certain criteria based on the requirements set by the researchers. The inclusion criteria in this study were all barbers in the city of Yogyakarta, not only using traditional razors but also using modern razors. While the exclusion criteria is the barber who at the time of taking the data, the barber was closed and do not willing to become a respondent.

IJPHS Vol. 6, No. 4, December 2017 : 337 - 342 
Instrument of research is The research instrument used is a knowledge and attitude questionnaire is adopted of Sugianto (2009) so it does not require validity and reliability test [10]. The questionnaire to assess the barber's behavior is done by looking directly at the barber's behavior while doing his job. Spearman analysis is used because the scale of the data set by the researchers is numerical data and has been tested normality. Normality test results show that all data is normally distributed so that it is eligible to proceed with Spearman Rho test.

\section{RESULTS AND ANALYSIS}

\subsection{Results}

Results of the univariate analysis were performed to describe the characteristics of research subjects and all the variables. The results can be seen in Table 1.

Table 1. Frequency Distribution based on Level Education and Information Resources

\begin{tabular}{lcc}
\multicolumn{1}{c}{ Variable } & Frequency & Percent $(\%)$ \\
\hline Education & & \\
Low & 102 & 95.33 \\
Height & 5 & 4.67 \\
Information resources & & \\
Teacher & 42 & 39.25 \\
Parents & 30 & 28 \\
Health workers & 50 & 46.73 \\
Friend & 46 & 42.99 \\
Newspaper & 62 & 57.94 \\
Magazine & 52 & 48.60 \\
Television & 82 & 76.64 \\
Radio & 46 & 42.99 \\
Internet & 69 & 64.49 \\
Total & 107 & 100 \\
\hline
\end{tabular}

Table 1 shows that of the 107 respondents, 102 respondents $(95.33 \%)$ educated. Respondent who had a barber behavior in an effort to prevent the spread of HIV/AIDS through a sterile razor blade is not good as much as 56 respondents $(52.34 \%)$. Judging from variable sources of information, the respondents received information about HIV/AIDS from television as much as 82 respondents $(76.64 \%)$ and the lowest source of information comes from the parents of 30 respondents $(28 \%)$. Respondent are less educated who have the bad behavior more than who have good manners where in college-educated respondents good behaviour number of respondents more than behaving well. Univariate analysis of the age variable, the number of consumers, price set by the barber, knowledge, attitudes and behavior can be seen in Table 2 .

Table 2. Frequency Distribution Characteristics of Subject Research based on Variable Age, Number of Consumers Price, Knowledge, Attitude, and Behavior

\begin{tabular}{lccc}
\hline \multicolumn{1}{c}{ Variable } & Min & Malue & Mean \\
\hline Age & 17 & 77 & 30.91 \\
Amount of Costumer & 6 & 100 & 31.28 \\
Price & 0 & 16 & 08.23 \\
Knowledge & 13 & 48 & 34.09 \\
Attitude & 19 & 40 & 31.06 \\
Behavior & 19 & 40 & 31.06 \\
\hline
\end{tabular}

Table 2 notes that the average age of respondents was 30.91, the number of consumers 31.28 , the price or tariff set by the barber IDR 8.230, 34.09 knowledge, attitudes and behavior amounting to 31.06. Level of education are grouped into two groups: low education as many as 102 people $(95.33 \%)$ and higher education by 5 votes (4.67\%). Based on univariate analysis based on the average value of the knowledge, attitudes and behavior of the data can be classified into risk group and the group is not at risk, namely knowledge (not good for 52 people and well for 55 people), attitude (not good as 56 people and is not good as much as 51 people), and behavior (not good as well as 56 and 51 people).

Based on the rate most people are able to reach a price set by a razor because the tariff ranges between IDR 6,000-10,000 and an average tariff of IDR 8, 230. Each barber shop has customers who visit 
the place. On average shaver have 32 customers each month. There are 56 respondents $(52.34 \%)$ have good attitude. Analysis of the relationship between knowledge, attitudes and behaviors are described in Table 3 .

Table 3. Correlation between Knowledge and Attitude Barber with a sterile Razor Usage Behavior in the Prevention of HIV/AIDS

\begin{tabular}{lcc}
\hline \multicolumn{1}{c}{ Variable } & $\mathrm{R}$ & $\mathrm{P}$ \\
\hline Number of Consumers & 0.07 & 0.45 \\
Price & 0.02 & 0.82 \\
Knowledge & 0.21 & 0.03 \\
Attitude & 1.00 & 0.00 \\
\hline
\end{tabular}

Table 3 describess the results of correlation analysis between external variables that the sheer number of consumers and price barber with a barber's behavior in the prevention of HIV/AIDS. Based on Spearman analysis showed that there was no relationship between the number of consumers and the behavior of barbers in the prevention of HIV/AIDS with the strength and direction of the relationship is very weak positive relationship. Likewise premises variable rates, showed no relationship between rates and the behavior of barbers in the prevention of HIV/AIDS with the strength of the relationship is very weak and the power of positive relationships.

The results of the analysis of the relationship between independent variables and the dependent variable is the barber's knowledge about HIV/AIDS premises $\mathrm{n}$ behavior using sterile razor blades in an effort to prevent HIV/AIDS evidenced by the value of $\mathrm{p}=0.03$ with the strength of the correlation is weak $\mathrm{r}=0.21$ and the direction of the relationship positive. Results of statistical analysis between variables attitude barber with behavioral variables using sterile razor blades in efforts to prevent HIV/AIDS proved significant, meaning that there is a relationship as evidenced by the value of $\mathrm{p}=0.00$ with the power of very strong correlation with the value of $\mathrm{r}=1.00$ and directions positive relationship.

Bivariate analysis showed that the variables of knowledge and attitude barber shown to be associated with behavioral variables barber use sterile razor in efforts to prevent HIV/AIDS, because there are two independent variables associated with the dependent variable analysis followed by multivariate analysis is linear regression. However, after checking normality, independence, multicollinierity, linearity and heteroscedastis, fifth assumptions are not met and therefore cannot proceed to the linear regression analysis.

\subsection{Discussion}

The measurement results with the use of knowledge barber razor sterile majority of respondents have a good knowledge of as many as 55 people (51.4\%) and who have no knowledge of either were 52 (48.6\%). Based on these results the proportion that has the level of knowledge of good and not good, do not differ much. Barber who has good knowledge to know and understand that the razor is used only once and not used for others.

Similarly, the measurement of attitudes, respondents who have an attitude of not good as 56 people $(52.34 \%)$ and both were 51 people $(47.23 \%)$. This result does away with the results behavior measurament. We known as behavior of the respondents have a good behavior in the prevention of HIV/AIDS implanted at $52.34 \%$, which has a good behavior by $47.66 \%$.

The results show that most respondents do not have a good attitude and behavior in the prevention of HIV/AIDS. Barber uses a razor for some customers and replaces it when the razor is not sharp anymore. Barbers also rarely use Personal Protective Equipment (PPE) such as sterile gloves. This is possible because the barber did not realize the importance of using PPE is that the Ministry of Manpower and Transmigration need to provide guidance on the importance of Health and Safety.

Barbers still use a razor for some customers to blunt without any decontamination/sterile [10]. Behavior that uses razor many times on different customers could be at risk in the spread of HIV AIDS. HIV virus is found in blood, semen and vaginal fluids. Use a razor if the skin and hurt the razor can be exposed to blood from customers. Razor is used many times in the event of injury to skin; the virus can enter through the wound. If a person has a positive attitude towards healthy behaviors particular, it will facilitate the person's presence in the emerging healthy behaviors (predisposing factors) [11].

Analysis of knowledge barber with behavioral HIV/AIDS prevention at the barber, based on Table 3 indicate a relationship with a value of $p=0.03$, with the strength of weak ties and the direction of a positive relationship means the better knowledge will became the better behaviour of barber worker in prevention HIV/AIDS. 
Observations in the field show that a person's behavior based on knowledge. Behavior is strongly influenced by the factor of knowledge and attitudes acquired. Knowledge is the result of the idea, based on the sensing process a person against a particular object using the five senses [12]. Most of the human senses, derived from the senses of sight and hearing [13]. Knowledge can be received through the learning process, so if want to know or understand something better study. From experience and research turned out behavior based on knowledge will be more effective than behavior that is not based on knowledge. Knowledge is a predisposing factor or factors that facilitate the emergence of behavior [14]. The study found there is a gap between knowledge and behavior on a barber, especially those who open a practice on the roadside [15]. A study shows the majority of barber educated low. They are the ones opening the stall by the side of the road. Most of them have low knowledge about HIV. This is because their education is low. Thus, this situation is potential in HIV transmission. The gap is very visible between the barber on the big salon and the one on the side of the road [16]. There was relationship between education and risk condition that are vulnurable to HIV transmission [17]. Research also indicates that there is inadequate awareness on the roadside barber about HIV transmission. Only $60.3 \%$ barbers use a new razor to customers and only $40 \%$ of the barber who use antiseptic after shave. This is because a weak education on the topic of HIV transmission [18]. The study found that $52 \%$ of barbers involved disinfectants use of kerosene. $48.3 \%$ disinfectant does not come from the original container. $53.4 \%$ uses the same brush to cleaning the clipper and brushing hair [19].

The study mentioned need a design and implementation of appropriate interventions to improve the perception of barbers about perceived vulnerability and reducing barriers to prevent the transmission of HIV/AIDS on the use of a razor [17]. The results of the studies advise the need for an intervention in the form of mass communications to specific communities such as barbers to increase their awareness about the disease that is transmitted through blood and educate them not to do practices that are not safe [20]. Another study also recommends that training to barbers for the prevention of blood-borne infections is strongly associated with their profession [6]. Finally, intervention not only given to people with HIV / AIDS, but also must involve the community including people related to HIV / AIDS transmission [21]. Barber knowledge will increase with intervention and barbers can provide health education to their customers [22].

The results of the analysis of the behavior of a variable number of customers showed no difference between the number of subscribers with the amount of customers that little of the behavior of HIV/AIDS prevention. Based on these results a variable number of customers are not a variable related to prevention behaviors. The results of the analysis variables haircut price behavior showed no difference in rates haircut costs with preventive behavior. Bad behavior is more common in places pieces that give rates low compared to the high price, but this difference was not statistically significant. This indicates that the price of a haircut is not a variable that affects behavior

\section{CONCLUSION}

Barber shop is one place where people use razors and places that do not have sterilizing equipment. Customers who use barber services to cut hair are at risk of being scratched by a razor when the scalp is shaved to protect their customer. The research found that there was a relationship between knowledge and attitude with behavior barbers in preventing transmission of HIV/AIDS through the razor in the city of Yogyakarta. Based on the discussion of this study, it can be concluded that there were relationship between knowledge, attitudes and barber behavior in HIV transmission.

\section{ACKNOWLEDGEMENTS}

Thank to Universitas Ahmad Dahlan Yogyakarta, which has been providing material support on this study.

\section{REFERENCES}

[1] UNDP, "Convention of Development Agenda," Nawa Cita, National Midterm Development Plan and Sustainable Development Goals, 2015.

[2] Ministry of Health Republic Indonesia, "Data HIV and AIDS in 1987-Directorat General of Control and Disease Eradication," 2016.

[3] Tupan, "Transmission and Prevention of AIDS in Indonesia," Baca, vol/issue: XXI(5), pp. 2-8, 1998.

[4] M. Mutocheluh and K. Kwarteng, "Knowledge and occupational hazards of barbers in the transmission of hepatitis B and C was low in Kumasi, Ghana Mohamed," Pan African Medical Journal, vol/issue: 20(260), pp. 1-7, 2015.

[5] Eltayeb N. H. and H. M. Y. Mudawi, "Knowledge and practice of barbers regarding transmission bloodborne viruses in Khartoum State," Annals of Tropical Medicine and Public Health, vol/issue: 6(1), pp. 80-83, 2013. 
[6] E. Amodio, et al., "Knowledge, attitudes and risk of HIV, HBV and HCV infections inhair dressers of Palermo city (South Italy)," Eur J Public Health, vol. 20, pp. 433-437, 2010.

[7] Biadgelegn F., et al., "Potential risk of HIV transmission in barbering practice in Ethiopia: Form public health and microbiological perspective," BMC Public Health, vol. 11, pp. 707, 2012.

[8] Q. Sholihah and R. Fauzia, "Correlation of razor hygiene with HIV disease transmission risk in barber shop," International Journal of Biosciences, vol/issue: 9(6), pp. 383-392, 2016.

[9] B. P. Atmaja and E. R. Ansari, "Relationship between knowledge and attitude barber's on HIV/AIDS behavioral prevention of Transmission of HIV/AIDS Transmission Through Razors," Jurnal Darul Azhar, vol/issue: 4(1), pp. $52-6,2018$

[10] H. Sugianto, "Barbers Behavior in Prevention of Transmission of HIV/AIDS through Razor in Malang," Medical Journal, vol/issue: 7(2), pp. 134-142, 2009.

[11] L. Rahayu, "Epidemic Alert: Guide to Layman,” Nuance Cendikia, Bandung, pp. 90-91, 2010.

[12] L. W. Green and M. W. Kreuter, "Health Promotion Planning: An Educational and Environmental Approach," Second Edition. USA: Mayfield Publishing Company, 2000

[13] Koentjaraningrat, "Introduction to Anthropology," Jakarta, Rineka Reserved, 2015.

[14] H. D. J. Maulana, "Health Promotion," Jakarta Book Medical Publishers EGC, 2009.

[15] Nath B., et al., "Profession of barbering: Unexplored issues in HIV/AIDS," CEGH, vol/issue: 1(2), pp. 67-73, 2013.

[16] F. Imran, et al., "Knowledge and Practices of Barbers Regarding HIV Transmission in Karachi : A Cross-Sectional Study," Jornal Community Health, vol. 39, pp. 951-955, 2016.

[17] M. Solhi, et al., "HIV prevention perception among barbers," Journal of Research \& Health, vol/issue: 4(1), pp. 592-598. 2014.

[18] F. I. Bawany, et al., "Knowledge and Practices of Barbers Regarding HIV Transmission in Karachi : A CrossSectional Study," Journal Community Health, vol. 39, pp. 951-955, 2014.

[19] O. S. Arulogun and Adesoro M. O., "Potential risk of HIV transmission in barbering practice among professional barbers in Ibadan, Nigeria," African Health Sciences, vol/issue: 9(1), pp. 19-25, 2009.

[20] M. K. Krishanani, et al., "Educational Intervention among Barbers to Improve Their Knowledge regarding HIV/AIDS: A Pilot Study from a South Asian Country," J Health Population Nutrition, vol/issue: 32(3), pp. 386390, 2014.

[21] Boneh G. and Jaganath D., "Performance as a component of HIV/AIDS education: Process and collaboration for empowerment and discussion," American Journal of Public Health, vol/issue: 101(3), pp. 455-464, 2011.

[22] Luque J. S., et al., "Qualitative systematic review of barber-administered health education, promotion, screening and outreach programs in african-american communities," Journal of Community Health, vol/issue: 39(1), pp. 18190, 2014

IJPHS Vol. 6, No. 4, December 2017 : 337 - 342 